\title{
EGO-NETWORK OF ISTVÁN BOCSKAI IN THE LIGHT OF HIS CORRESPONDENCE (1576-1598) ${ }^{1}$
}

\author{
Krisztina Juhász \\ MTA-SZTE Research Group of the Ottoman Age (ELKH), Szeged (Hungary)
}

\begin{abstract}
István Bocskai (1557-1606) was an outstanding person of the Hungarian history at the turn of the $16^{\text {th }}$ and $17^{\text {th }}$ century, who is one of the greatest letter-writer in the early modern age. The total exchange of letters (about 500 pieces) has been scattered over 30 various source-publications and source-books, while the unpublished letters can be found in different Hungarian and foreign archives. In my paper I focus on the social network of István Bocskai in two less-known periods, using a special approach (ego-network). My research is based on the correspondence of István Bocskai, that is one group of ego documents. My aim is to present, by 134 records (letters and testimonies) clean-cut, main tendencies.
\end{abstract}

Keywords: István Bocskai, correspondence, social network, ego-network, early modern age.

\section{INTRODUCTION}

In the past few years, the interest in the social network research has been livened up in several fields of science, not only abroad, but also in Hungary. ${ }^{2}$ In historical

1 The research related to this paper was supported by the Ministry of Human Capacities (Emberi Erőforrások Minisztériuma) through the grant (code no. 20391-3/2018/FEKUSTRAT). This paper is written as a contribution of the Interdisciplinary Centre of Excellence, the Department of Medieval and Early Modern Hungarian History (Faculty of Humanities and Social Sciences) (University of Szeged) and the MTA-SZTE Research Group of the Ottoman Age. I am grateful to Sándor László Tóth (University Professor, Department of Medieval and Early Modern Hungarian History) and to Sándor Papp (Head of the MTA-SZTE Research Group of the Ottoman Age) who provided useful pieces of advice during the research process and writing this study. Furthermore, my thanks also go to Gellért Ernő Marton for the assistance provided during the writing of this paper.

2 See as the most important works: G. Balázs, L. Kovács, V. Szőke (eds.), Hálózatkutatás. Interdiszciplináris megközelitések, Budapest 2012; G. Balázs, L. Kovács, V. Szőke (eds.), 
research, there is a source group that provides data not only for philological analysis or for the reconstruction of biographies or historical events, but offers possibility to interpret them as a network-model. These sources are letters or correspondence constituting the most important instruments of written communication and forming one group of ego documents. With the help of the new, modern methodological approaches, comprehensive and data-oriented studies and quantitative analyses can be prepared.

$\mathrm{My} \mathrm{PhD}$ thesis in progress focuses on the analysis of the correspondence of István Bocskai (1557-1606), who can be mentioned among the greatest personalities of letter-writers. ${ }^{3}$ The local distribution of surviving letters shows a rather varied picture. The total exchange of letters has been scattered over 30 various source-publications and source-books ${ }^{4}$ (about 400 documents), while the unpublished letters,

Hálózatkutatás. Diszciplinák és metszéspontok, Budapest 2013; S. Papp, "Egy Habsburg-követ, Simon Reniger oszmán kapcsolathálózata Konstantinápolyban. Vezírek, muftik, magyar renegátok," Aetas 2016, no. 3, pp. 40-53; D. Kovács, "Az ecsedi udvar. Szervitori hivatás és kapcsolatrendszer Báthory István famíliájában,” Századok 2016, no. 4, pp. 911-944.

3 L. Hopp, “A magyar levélmüfaj történetéböl” [in:] Irodalom és felvilágosodás. Tanulmányok, eds. J. Szauder, A. Tarnai, Budapest 1974, pp. 506.

4 K. Szabó, "Bocskai István politikai levelezése,” Magyar Történelmi Tár 1882 (I, pp. 1-33; II, pp. 209-234); Á. Szalay, "Régiségek. Magyar levelek a XVIdik és XVIIdik századból," Tudományos Gyüjtemény 1830, no. 7, pp. 111-114; Á. Szalay, “Magyar régiségek,” Tudományos Gyüjtemény 1831, no. 4, pp. 109-123; J. Kemény, I. Nagy Ajtai Kovács (eds.), Erdélyország Történeti Tára egykorú s magyar nyelven készitett történetiratok-, levelek-, országgyülési végzések- és törvénycikkelyekböl, II, (1566-1613) Kolozsvár 1845; P. Jászay, “A magyar nyelv történetének vázlata” [in:] A Magyar Tudós Társaság Évkönyvei. VI. 1840-1842, Buda 1845, pp. 261-297; I. Nagy, I. Páur, K. Ráth, D. Véghely (eds.), Hazai okmánytár. Codex diplomaticus patrius I, Győr 1865, pp. 417, 419-420, 471-474. From the series of I. Mikó (ed.), Erdélyi Történelmi Adatok, Kolozsvár, vol. I (1855), pp. 213-215, vol. III (1858), pp. 320-321, vol. IV (K. Szabó (ed.), 1862), pp. 321-322, 342-344, 346-350; K. Thaly, "Bocskay István leveles könyve," Magyar Történelmi Tár 1874, pp. 63-120; K. Thaly, "Levél Bocskaitól s Homonnai Bálinttól," Magyar Történelmi Tár 1881, pp. 583-585; S. Szilágyi, "Bocskai István és Illésházy István levelezése 1605-ben és 1606-ban,” Magyar Történelmi Tár 1878 (I, pp. 1-84; II, pp. 271-338; III, pp. 577-652); L. Kemény, "Bocskai István levelei Kassa városához," Magyar Történelmi Tár 1904, pp. 458-47. From the series of S. Szilágyi (ed.), Erdélyi országgyülési emlékek. Monumenta Comitialia Regni Transylvaniae, Budapest, vol. IV (1878), pp. 297-298, 416-417, 419424, 463, 465-467, 478-486, 500; vol. V (1879), pp. 100-105, 360-362, 371-372, 376-377, 386-388, 400-401, 402-408, 409-414, 429-430. From the series of V. Fraknói Dr., Á. Károlyi Dr., Magyar országgyülési emlékek. Monumenta Comitialia Regni Hungariae, Budapest, vol. X (1890), pp. 606-612; vol. XI (Á. Károlyi Dr., 1899), pp. 144-146, 148-161, 416-417, 437-445, 471-472, 481-482, 495-498, 501-509, 743-744, 773-787, 794-804; vol. XII (1917), pp. 422-425, 688-690, 729-730, 733-738. From the series of E. de Hurmuzaki, Documente privitóare la Istoria Românilor, Bucuresci, vol. III/1 (1880), pp. 347, 350, 352-356, 401, 405; vol. IV/1 (1882), pp. 421-414; vol. XII (1903), pp. 232, 220, 232-233, 242, 280-281, 324-325, 353, 476, 635; vol. XV/1 (1911), p. 403; vol. XV/2 (1913), pp. 817-819. From the series of A. Veress Dr., Documente privitoare la istoria Ardealului, Moldovei şi Ţării-Românesti, IV, Bucureşti 1932, pp. 43-44, 154-158; vol. V (1932), pp. 354-356; vol. VII (1934), pp. 250-252, 256259, 264-265; E. Veress Dr., Basta György hadvezér levelezése és iratai, I, Budapest 1909, pp. 300, 304; K. Benda (ed.), Bocskai István: Levelek, s. 1. 1992; L. Nagy, “Okmányok a Bocskai szabadságharc idejéböl,” Hadtörténelmi Közlemények 1956, pp. 291-332; L. Nagy, A Bocskai szabadságharc katonai története, Budapest 1961, pp. 381-384; M. Nyak as, A bihari kishajdú városok története, Debrecen 2005, pp. 341-342; L. Nagy, Iratok Bocskai István és kora történetéhez, Debrecen 2005; M. B alázs, "Ecsedi Báthory István levelei Bocskaihoz,” Irodalomtörténeti dolgozatok 1972, pp. 41-49; A. Molnár, Stefan 
which I discovered (about 100 pieces), can be found in different Hungarian ${ }^{5}$ and foreign archives. ${ }^{6}$

István Bocskai was born in Kolozsvár (present day Cluj-Napoca in Romania), in 1557 and became an outstanding person at the turn of the $16^{\text {th }}$ and $17^{\text {th }}$ century. ${ }^{7}$ In the first phase of the so-called Fifteen Years' War or Long Turkish War (1591/93-1606), ${ }^{8}$ he was one of the main supporters of the alliance between Transylvania and the Habsburg Empire against the Ottomans. Then, close to the end of the war, from 1604 he led the revolt of the Kingdom of Hungary against the Habsburg ruler, Emperor Rudolf II (1552-1612). ${ }^{9}$ Bocskai was elected a Prince of Transylvania (February 1605) and Hungary (April 1605). ${ }^{10}$

In my study I focus on the social network of István Bocskai. Since it changes in size, density and composition in time, in my paper I decided to limit the time period of the examined entire network and to expound two less-known periods, using a special approach. Typically, the social network analysis examines a specific, welldefined group consisting of a definable number of persons. However, there is another approach. In this case, the research focuses not on a group, but on an individual and on his or her relations. The ego-network shows the connections between a certain individual (the so-called ego) and the persons directly associated with him (the socalled alter/alters). ${ }^{11}$

Bocskay als Staatsmann und Persönlichkeit im Spiegel seiner Briefe, 1598-1606, 1983; G. Bay erle, The Hungarian letters of Ali Pasha of Buda 1604-1616, Budapest 1991, pp. 33-35, 48-51, 60-62, 70-73, 76; I. Fazekas, "Négy levél Bocskai István bécsi és prágai tartózkodásához (1572, 1576)," Lymbus 2003, pp. 19-24; V. Vadász, "Egy prédikátor levelei Bocskaihoz 1605 tavaszán," Aetas 2005, no. 3, pp. 155-161; M. Nyakas, Bocskai István váradi fökapitányt illetö levelek, Debrecen-Nagyvárad 2009; K. Juhász, "List Štefana Bočkaja adresovaný mestu Banská Bystrica (Szerencs, 24. marca 1605.)," Acta Historica Neosoliensia 2016, no. 1, pp. 78-88; E. Veress, Zamoyski János kancellár levelezése magyarokkal (1576-1605), Magyar Tudományos Akadémia Könyvtár és Információs Központ, Kézirattár, Veress Endre hagyaték, Ms. 433.

5 Magyar Nemzeti Levéltár Országos Levéltára (in the following: MNL OL); Magyar Nemzeti Levéltár Borsod-Abaúj-Zemplén Megyei Levéltár; Kecskeméti Református Egyházközség Könyvtára és Levéltára; HM HIM Hadtörténeti Levéltár [HM HIM Archive of Military History] (in the following: HM HIM HL).

6 Österreichisches Staatsarchiv (in the following: ÖStA); Archivele Nationale Cluj.

7 For the life of István Bocskai, see: K. Benda, Bocskai István, Budapest 1993; L. Nagy, Egy szablyás magyar úr Genfben. (A sokarcú Bocskai István), Hajdúböszörmény 2002; A. Szabó, , Téged Isten dicsérünk”. Bocskai István, Erdély és Magyarország fejedelme, Budapest 2006; N.G. Etényi, I. Horn, P. Szabó, Koronás fejedelem. Bocskai István és kora, Budapest 2006.

8 For the summary of the history of the Fifteen Years' War, see: S. L. Tóth, A mezökeresztesi csata és a tizenöt éves háború, Szeged 2000; P.Z. Bagi, A császári-királyi mezei hadsereg a tizenöt éves háborúban. Hadszervezet, érdekérvényesités, reformkisérletek, Budapest 2011.

9 He was Holy Roman Emperor (1576-1612), King of Hungary (1576-1608) and King of Bohemia (1576-1611).

10 For the event of Bocskai's revolt summary, see: L. Nagy, A Bocskai szabadságharc katonai története, Budapest 1961; S. Papp, Török szövetség - Habsburg kiegyezés. A Bocskai-felkelés történetéhez, Budapest 2014.

11 A.G. Feleky, “Az egyén társadalmi beágyazottságának egoháló alapú vizsgálata," Belvedere Meridionale 2012, no. 1, pp. 58-67; K. Sántha, "Én-központú hálózatok kvalitatív elemzése," 


\section{SOURCES OF MY RESEARCH}

The basis of my research is therefore the correspondence of István Bocskai. We consider a written message to be a letter, that is not of legal character, replaces live communication and serves to notify the recipient. ${ }^{12}$ I work with and differentiate two types of letters. On the one hand, the already published or newly discovered missiles, that is, really sent, received and in some form - published and/or original - preserved letters. On the other hand, I have included testimonies (testimonia) in the research, that is, references to letters in the correspondence, which were sent and received, but did not survive. ${ }^{13}$ In most cases, the testimonium provides little information, usually the name of the letter-writer and addressee of the letter, and in some instances reference can be found to the content of the letter or part of the letter, and we can also conclude the date of writing. The examination of these references is important, because in most cases just from these testimonies we can get some information about the lost letters. With the help of the remaining letters and the testimonies (inside references to letters), the correspondence and the reconstruction of István Bocskai's social network can show a more accurate picture.

My research was helped by rendering the correspondence of Bocskai into a database. During this process, I registered the date and place of the letter, the name and title of the letter-writer and the addressee, the extract of the document, the archival pressmark, the bibliographic information of the published letter, the type and language of the document, the number and characteristics of the testimonies. The database may change slightly in the future, depending on the results of further research, therefore it is worth emphasizing that the data required for the preparation of this publication reflects the state of this database as of August 12, 2019.

There are several possibilities for analyzing the network based on the information that can be filtered by sorting out the correspondence of Bocskai into the mentioned database. The analysis of the ego-network can be done both at the network level and in the field of relationships. Now I'm going to present, on the one hand, how the number of letters and relations of the ego changed during the two examined periods; namely, the size of the ego-network, the magnitude and density of network growth. On the other hand, I study what can be said about the characteristics of the alters registered in the correspondence, that is, the composition of the ego-network. It is important to emphasize, that only one type of connection, the registered exchange of letters, binds the members of the network under investigation. In this paper, I do not go into the detailed analysis and presentation of the individual relationships due to limitations of size.

Neveléstudomány: Oktatás, kutatás, innováció 2016, pp. 54-66. For the networks' summary, see: A-L. B arabási, A hálózatok tudománya, Budapest 2016.

12 I. Bakács, "A missilis," Levéltári Közlemények 1966, no. 1, pp. 21-22; L. Hopp, “A magyar levélműfaj történetéböl," pp. 501-502.

13 For the concept of testimonia, see: Á.T. Horváth, A Római Birodalom latin nyelvü levelezésének három évszázada, Szeged 2002, pp. 15-16. 


\section{EGO-NETWORK OF ISTVÁN BOCSKAI IN 1576-1591}

I set 1576 as the starting year for the formation of time limits, because István Bocskai's first surviving letters were written in this year. ${ }^{14}$ There is no reference to a previous letter. For the reason that István Bocskai received the appointment of Commander-in-chief of Várad at Spring 1592, and since then his correspondence became different in character in several respects, the end of the first period can be put at 1591. In this period, I registered 16 letters, which include 5 published and 11 unpublished (newly discovered by me) documents. This letter number may be completed by a reference to 5 more letters. So, I know 21 letters altogether.

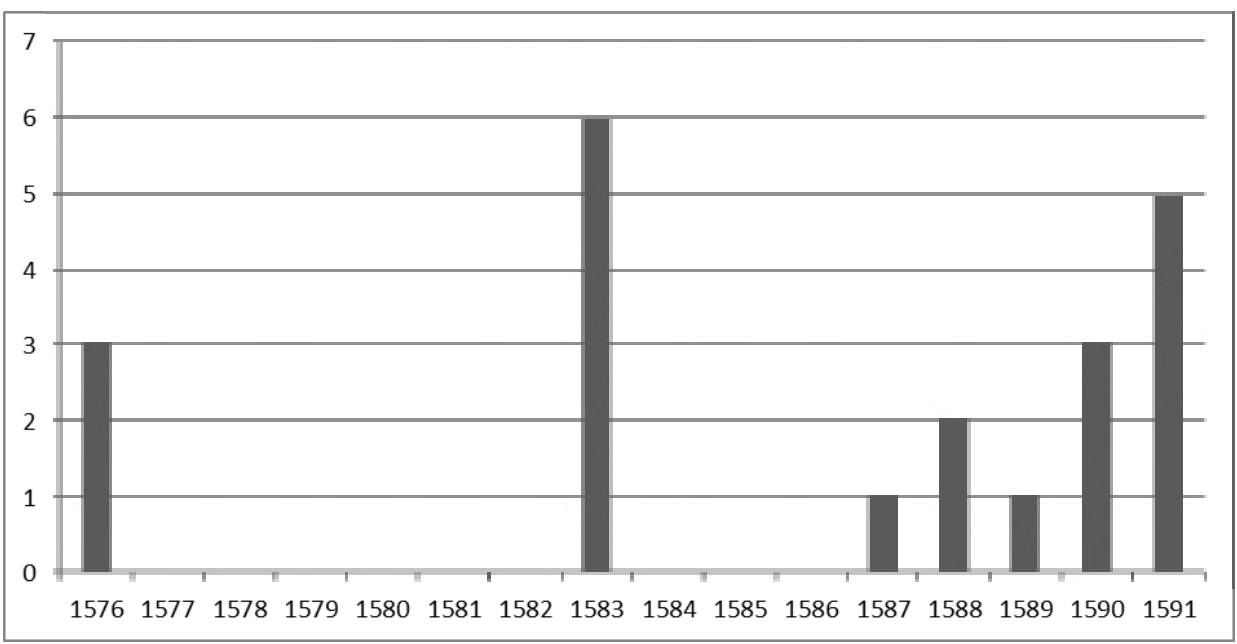

Fig. 1. The time distribution of letters (1576-1591)

The temporal distribution of letters is sporadic. The exchange of letters at early spring of 1576 form a separate unit. The first known letters relate to the stay and absence of the young, 19-year-old István Bocskai in Vienna. ${ }^{15} \mathrm{He}$ was in the service of the Habsburgs for eight years in Prague and Vienna. ${ }^{16}$ His return to Transylvania in 1576 coincided with the crowning of István Báthory (1533-1586) as a Polish King (1576-1586) and the beginning of the rule of the Holy Roman Emperor, Rudolf II as a Hungarian King. Since István Báthory did not give up his rule over Transylvania, his elder brother, Kristóf Báthory (1530-1581) was appointed as a voivode, later his

14 I. Fazekas, "Négy levél...," pp. 19-24.

15 Ibidem, pp. 22-24.

16 For the period of his service in the Habsburg imperial court, see: N.G. Etényi, I. Horn, P. Szabó, Koronás fejedelem, pp. 43-52; I. F a z e k a s, “Adalékok az ifjú Bocskai István bécsi udvarban eltöltött éveihez," Studia Caroliensia 2006, no. 1, pp. 73-85. 
son, Zsigmond (1572-1613; after the death of István Báthory he became the Prince of Transylvania (1594-1598, 1598-1599, 1601-1602)) who governed the Ottoman vassal state, the Transylvanian Principality. At the time of Zsigmond's minority earlier a governing body, later a triumvirate (Sándor Kendy, Farkas Kovacsóczy, Sándor Sombory), ${ }^{17}$ then up to the majority of Zsigmond one governor (János Ghiczy) directed Transylvania. ${ }^{18}$

The seven years between the spring of 1576 and the autumn of 1583 are unusual, because there are no data about surviving letters or testimonies. Considering that István Bocskai was then a well-managed young man at the beginning of his career, supported by his relatives in the ruling Báthory family ${ }^{19}$ and working in their immediate neighborhood, ${ }^{20}$ he cannot be assumed to have not written or received any letters in seven years. This hiatus can be probably explained by reasons of textual legacy.

As for the size of the ego-network, in case of 12 of the 21 registered letters, István Bocskai is the letter-writer, and in 9 cases the addressee, the number of alters is 13. Regarding relationship intensity, two people can be highlighted: Jan Zamoyski, the Polish Chancellor, with four letters and Kristóf Csapy, the Captain of Kálló, with 3 registered letters in the network. Mutual, verifiable communication from both sides can be proved in case of two persons (Johann Trautson and Jan Zamoyski).

As for the composition of the network, that is, which groups are linked with the ego, István Bocskai, I considered the positions of the persons in the social and political structure, and their relationships with the ego. It is important to emphasize that there are overlaps between the groups in the classification of individuals.

Into the first group I put the high-ranking individuals, especially rulers, and highranking officials in their surroundings. Therefore, we can mention János Gálffy, princely councillor from the political leadership of Transylvania; ${ }^{21}$ Maximilian II, the Roman Emperor and Hungarian King, ${ }^{22}$ as well as his marshal, Johann Trautson; ${ }^{23}$ and Jan Zamoyski from the Polish-Lithuanian Commonwealth. So, there are 4 persons altogether.

17 I. Horn, “Az erdélyi hármastanács kormányzata (1583-1585),” Századok 2006, no. 4, pp. 883925.

18 For the regency of János Ghiczy, see: I. Horn, A hatalom pillérei: A politikai elit az Erdélyi Fejedelemség megszilárdulásának korszakában (1556-1588), DSc doctoral thesis, 2012, pp. 277-296.

19 István Bocskai was Kristóf Báthory’s brother-in-law and Zsigmond Báthory’s uncle by his sister, Erzsébet Bocskai.

20 István Bocskai became the member of the princely family. In 1581, after the death of Kristóf Báthory, Bocskai was one of the persons, who managed the matters about the testament of Kristóf Báthory. Bocskai became a member of the governing body, which directed Transylvania, after this he was the butler near the young prince, Zsigmond Báthory. For this period, see: I. Horn, "Bocskai István a Báthoryak udvarában,” Publicationes Universitatis Miskolciensis. Sectio Philosophica 2018, no. 2, pp. 47-56.

${ }^{21}$ K. Benda (ed.), Bocskai István: Levelek, p. 17.

22 I. Fazekas, "Négy levél...," pp. 22-23.

23 Ibidem, pp. 23-24. 
Jan Zamoyski (1542-1605) was appointed earlier Chancellor, later Grand Chancellor, and Grand Hetman of the Crown, by István Báthory, the Polish King. ${ }^{24}$ In 1583, Zamoyski married his third wife, Krisztina Báthory, who was a niece of István Bocskai. Thus, Bocskai and Zamoyski became relatives at that time. They got into contact at the latest at the time of the wedding, as the letter from September 1583 is a courtesy letter confirming their relationship. ${ }^{25}$ After the death of Krisztina Báthory in 1590, the diplomatic aspect of this nexus appeared. István Bocskai personally attended Krisztina (Griselda) Báthory's funeral in Zamość. Then, as a member of the embassy, he treated with Zamoyski, whose task was to settle the conflict that had arisen about the marriage portion of his deceased wife, Krisztina Báthory. ${ }^{26}$

In the second group I put people who hold military offices, where there is one alter, Kristóf Csapy, the Captain of the fortress of Kálló, located at the territory of the Kingdom of Hungary. Their contact was clearly based on geographical proximity. ${ }^{27}$

From the aspect of research, another group can be distinguished, that includes servitors, who were in the service of István Bocskai. These four persons were working on the estates of Bocskai, which were in the Bihar County (belonging then to the Transylvanian Principality). In these letters we find data about two kinds of servitors: the economic and prefectural servitors. The staff of the first group was better documented, the three persons (Gáspár Nagy, István Kun, Ferenc Wentey) belonging to this group were primarily engaged in the performance of economic tasks, such as the supervision and management of agricultural work and the settlement of the affairs of the peasants. ${ }^{28}$ In the prefectural layer, one person can be registered, Tamás Szabó, who was the prefect of the castle of Kereki in Bocskai's possession at that time. ${ }^{29}$

To the group, which exclusively consists of members of family and relatives, belongs one alter, Bocskai's mother, Krisztina Sulyok. ${ }^{30}$ The last category is made up of other people not listed elsewhere. We can find here three alters, Miklós Zólyomi, ${ }^{31}$ Pál Telegdy, who was a Hungarian baron, ${ }^{32}$ and one unknown person..$^{33}$

The scene of the spatial distribution of the correspondence and the network was shaped by the current writers. Bocskai addressed his letters mostly from four

24 For the relationship of Jan Zamoyski and István Báthory, see: E. Veress, Zamoyski János; P. Balla, "Báthori István király és Jan Zamoyski kancellár kapcsolata - egy sikeres együttmúködés története," Historia Nostra 2013, no. 1, pp. 4-23.

25 MNL OL Esterházy család hercegi ágának levéltára P 108 (in the following: P 108), Repositorium (in the following: Rep.) 46. Fasciculus (in the following: Fasc.) G. Numerus (in the following: Nr.) 229.

26 MNL OL P 108. Rep. 98. Fasc. H. Nr. 178/A.; MNL OL P 108. Rep. 98. Fasc. H. Nr. 178/B.

27 MNL OL Zichy család zsélyi levéltára P 707 (in the following: P 707) Missiles, XXXII. sorozat (in the following: sor.) Nr. 00389.; MNL OL P 707 Missiles, XXXII. sor. Nr. 00390.; MNL OL P 707 Missiles, XXXII. sor. Nr. 00391.

28 MNL OL P 108. Rep. 98. Fasc. H. Nr. 77.; MNL OL P 108. Rep. 46. Fasc. G. Nr. 233.; MNL OL P 108. Rep. 46. Fasc. G. Nr. 232.

29 MNL OL P 108. Rep. 46. Fasc. G. Nr. 231.

30 K. B e n d a (ed.), Bocskai István: Levelek, p. 17.

31 MNL OL P 707 Missiles, XXXII. sor. Nr. 11581.

32 Ibidem, p. 18.

33 Ibidem, p. 17. 
settlements of the Transylvanian Principality: from the prince's centre (Gyulafehérvár, present day Alba Iulia in Romania) and the villages in his possession (Kereki, present day Nagykereki in Hungary; Kismarja; Székelyhíd present day Săcueni in Romania); and only one from the territory of the Kingdom of Hungary (Munkács, present day Мукачево in Ukraine). Bocskai received letters beyond these borders; besides Vienna, he got letters from two settlements of the Kingdom of Poland; Zamość and Kraków.

\section{EGO-NETWORK OF ISTVÁN BOCSKAI IN 1592-1598}

Zsigmond Báthory, the Transylvanian Prince appointed his uncle, István Bocskai as the Commander-in-chief of Várad (was the centre of the so-called Partium - four counties belonging to Transylvania then) in May 1592. Bocskai's high office held for six years ranked him immediately after the prince of Transylvania. The Commanderin-chief of Várad commanded the most important fortress of Transylvania, and also, as Chief bailiff reeve the county of Bihar, and he had both military and diplomatic tasks and responsibilities. ${ }^{34}$ The following data also illustrates the change in the network. From this second period examined (1592-1598), 25 letters published so far have been supplemented with 36 new documents, the number of testimonies in them are 52. So, I can work altogether with 113 records. In these letters, István Bocskai appears as a writer 70 times and in 43 cases as a recipient. The number of correspondents, that is, the number of alters, is 33 . That is, compared to the previous period, the number of correspondence increased fivefold, and the number of contacts was almost triple. The time distribution of letters is steadier than in the previous period, but I could register only one letter from 1593.

Considering the composition of the network, it can be stated that relations organize into more clusters than before, that is, new bonds appear, and the clusters are more complex. A group of rulers/high-ranking officials and people in their immediate surroundings comes into view. However, I registered only then Rudolf II, the Holy Roman Emperor, and Hungarian and Czech King, ${ }^{35}$ Zsigmond Báthory, the Prince of Transylvania, ${ }^{36}$ as well as those, who worked in their immediate surroundings, altogether six people. From Transylvania two councillors of the Transylvanian

34 Ford the obligations in detail, see: M. Nyakas, Bocskai István, pp. 10-13; P. Gyulai, "Tanácsi tükör 1585" [in:] Janus Pannonius. Magyarországi humanisták, ed. T. Klaniczay, Budapest 1982, pp. 1255-1266.

35 K. Benda (ed.), Bocskai István: Levelek, pp. 27-28; L. N a g y, Iratok Bocskai István, pp. 83-85.

36 K. Benda (ed.), Bocskai István: Levelek, pp. 19-22.; M. N y a k a s, Bocskai István, pp. 13-15, 69-70, 341-342. 
Prince (György Ravazdy, ${ }^{37}$ Gergely Csáky ${ }^{38}$ ) and János Bernárdffy, the secretary of the chancellery ${ }^{39}$, were in contact with István Bocskai, while from the Habsburg court Simon Forgách, a councillor ${ }^{40}$ and Archduke Ferdinánd ${ }^{41}$ can be mentioned. Their correspondence concerns almost without exception political matters. The previously registered Polish relationship in correspondence cannot be proved in this period. In the group of family reappears one person, an unknown relative from Szentjobb (present day Sâniob in Romania). ${ }^{42}$

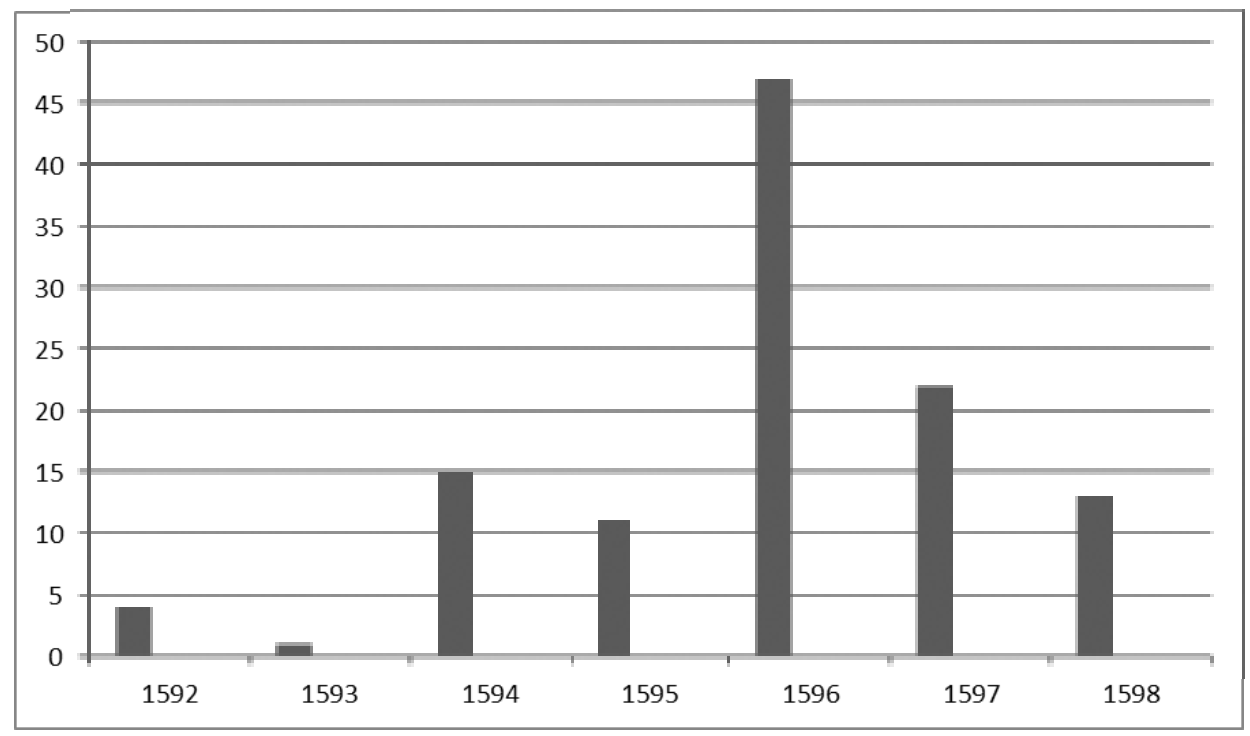

Fig. 2. The time distribution of letters (1592-1598)

There is a huge group of contacts established by the Commander-in-chief of Várad and Chief bailiff of the Bihar county, which category can be divided into five components, sub-groups. In the first sub-group, the range of persons in the military office expanded in size and function. Three (György Barbély, the Transylvanian

37 MNL OL Magyar Kamara Archívuma (in the following: MKA) E 204. Missiles, Fasc. 6. István Bocskai to György Ravazdy (Kassa, July 11, 1595).

38 MNL OL MKA E 204. Missiles, Fasc. 8. Gergely Csáky to István Bocskai (Körösszeg, June 11, $1595)$.

39 E. de $\mathrm{H}$ u r m u z a k i, Documente privitóare, XII, p. 353.

40 K. Benda (ed.), Bocskai István: Levelek, pp. 18-19.; HM HIM HL VII/2. Törökkori Gyüjtemény, $1594 / 41$.

${ }^{41}$ ÖStA Haus-, Hof- und Staatsarchiv (in the following: HHStA), Länderabteilungen, Ungarische Akten (in the following: UA), Allgemeine Akten (in the following: AA), Karton (in the following: Kt.) 127/128. Konvolut (in the following: Konv.) A. fol. 41-42. István Bocskai to Archduke Ferdinánd (Gyulafehérvár, April 8, 1595).

42 MNL OL MKA E 204. Missiles Fasc. 6. István Bocskai to György Ravazdy (Kassa, July 11, $1595)$. 
general, ${ }^{43}$ Eölveti Nagy Gergely, the Captain of guardsman, ${ }^{44}$ Péter Giczy, the Captain of Sarkad ${ }^{45}$ ) of the six persons in this category belonged to Transylvania, and three (Kristóf Csapy, the Captain of Kállóo, ${ }^{46}$ Pál Nyáry, the Captain of Eger, ${ }^{47}$ Christoph von Teuffenbach, the Captain of Kassa ${ }^{48}$ ) to Hungary. István Bocskai, as Commander-in-chief of Várad, was in close contact with the captains of the major castles of the Hungarian Kingdom. Analyzing the content of the correspondence with them, it can be concluded that two (Péter Giczy, Pál Nyáry) of them might be integrated into István Bocskai's spy network. Their letters are a kind of spy reports related to the military events of the Fifteen Years' War. In Bocskai's spy network I can register one more person (István scribe) in this period. ${ }^{49}$

Considering the density of connections, the cluster of officials of Várad seems to be the most important group. Although the number of alters are two, the intensity of the exchange of letters is high, 56 letters can be registered altogether, that is to say, exactly $50 \%$ percent of the total correspondence of this period maintained with the alters, who are included in this group. Generally speaking about the composition of this layer, these persons are typically located around Várad, the residence of the Commander-in-chief and the centre of Eastern Hungarian parts of Transylvania (Partium). Particular attention should be paid to Márton Köveskúti, the provisor of Várad with whom I have documented 46 exchange of letters altogether. ${ }^{50}$ The first

43 K. Benda (ed.), Bocskai István: Levelek, pp. 19-22.

44 MNL OL MKA E 204. Missiles, Fasc. 6. István Bocskai to Márton Köveskúti (Újvár, January 26, 1597).

45 L. Nagy, Iratok Bocskai István, pp. 68-69.

46 MNL OL P 707 Missiles, XXXII. sor. Nr. 00392; MNL OL P 707 Missiles, XXXII. sor. Nr. 00393.

47 M. Nyakas, Bocskai István, pp. 23-26.

48 E. de Hurmuzaki, Documente privitóare, XII, p. 232.

49 M. Nyakas, Bocskai István, pp. 21-23.

50 MNL OL MKA E 204. Missiles, Fasc. 6. István Bocskai to Márton Köveskúti (Tarcsa, September 24, 1595); MNL OL MKA E 204. Missiles, Fasc. 6. István Bocskai to Márton Köveskúti (Gyulafehérvár, February 1, 1596); MNL OL MKA E 204. Missiles, Fasc. 6. István Bocskai to Márton Köveskúti (Gyulafehérvár, February 11, 1596); MNL OL MKA E 204. Missiles, Fasc. 6. István Bocskai to Márton Köveskúti (Gyulafehérvár, March 14, 1596); MNL OL MKA E 204. Missiles, Fasc. 6. István Bocskai to Márton Köveskúti (Gyulafehérvár, March 27, 1596); MNL OL MKA E 204. Missiles, Fasc. 6. István Bocskai to Márton Köveskúti (Gerend, April 14, 1596); MNL OL MKA E 204. Missiles, Fasc. 6. Márton Köveskúti to István Bocskai (Várad, 24 May 1596); MNL OL MKA E 204. Missiles, Fasc. 6. István Bocskai to Márton Köveskúti (Temesvár, June 10, 1596); MNL OL MKA E 204. Missiles, Fasc. 6. István Bocskai to Márton Köveskúti (Szentjobb, August 13, 1596); MNL OL MKA E 204. Missiles, Fasc. 6. István Bocskai to Márton Köveskúti (Gyalu, September 27, 1596); MNL OL MKA E 204. Missiles, Fasc. 6. István Bocskai to Márton Köveskúti (Gyulafehérvár, December 13, 1596); MNL OL MKA E 204. Missiles, Fasc. 6. István Bocskai to Márton Köveskúti (Gyulafehérvár, December 31, 1596); MNL OL MKA E 204. Missiles, Fasc. 6. István Bocskai to Márton Köveskúti (Kapjon, January 17, 1597); MNL OL MKA E 204. Missiles, Fasc. 6. István Bocskai to Márton Köveskúti (Újvár, January 26, 1597); MNL OL MKA E 204. Missiles, Fasc. 6. István Bocskai to Márton Köveskúti (Gyulafehérvár, February 20, 1597); MNL OL MKA E 204. Missiles, Fasc. 6. István Bocskai to Márton Köveskúti (Gyulafehérvár, February 26, 1597); MNL OL MKA E 204. Missiles, Fasc. 6. István Bocskai to Márton Köveskúti (Gyulafehérvár, February 27, 1597); MNL OL MKA E 204. Missiles, Fasc. 6. István Bocskai to Márton Köveskúti (Gyulafehérvár, March 8, 1597); MNL OL MKA E 204. Missiles, Fasc. 6. István Bocskai to 
known letter is dated September 24, 1595, and then the letters follow each other periodically throughout the examined period until August 10, 1598. The provisor was the leader of the estate around the castle, who was in co-ordinative relationship with the Commander-in-chief of Várad, and his activities were primarily of economic nature..$^{51}$ The other member of this group is György Király, the vicecaptain of Várad, who exchanged ten letters with István Bocskai. ${ }^{52}$ The correspondence of the three persons gives us an insight into the life of the estates and the headquarter of Várad, and at the same time the relationship between the ego and the alters can be reconstructed. However, the analysis of this is not a part of this paper. The dense connection of István Bocskai with these persons connected to Várad shows that although he should have stayed in Várad, military and diplomatic missions often called him away from his place of service. Thus, dealing with matters related to Várad often required written communication.

The number of servitors doubled compared to the previous period, so this is the most contacted layer in the two examined periods; Pál Örvéndy, ${ }^{53}$ an unknown leaseholder from Szilágy, ${ }^{54}$ Péter Csukát, ${ }^{55}$ Péter Mohácsi, ${ }^{56}$ Máté scribe, ${ }^{57}$ Gergely Lippay, ${ }^{58}$ János Kereky, ${ }^{59}$ István Somlyai. ${ }^{60}$ The correspondence between István Bocskai and the alters concerns mainly economic tasks.

Márton Köveskúti (Gyulafehérvár, May 3, 1597); MNL OL MNL OL E 204. Missiles, Fasc. 6. István Bocskai to Márton Köveskúti (Gyulafehérvár, May 12, 1597); MNL OL MKA E 204. Missiles, Fasc. 6. István Bocskai to Márton Köveskúti (Gyulafehérvár, May 17, 1597); MNL OL MKA E 204. Missiles, Fasc. 6. István Bocskai to Márton Köveskúti (Gyulafehérvár, October 20, 1597); MNL OL MKA E 204. Missiles, István Bocskai to Márton Köveskúti (Gyulafehérvár, August 10, 1598); Á. Szalay, "Régiségek...," pp. 111-113.

${ }^{51}$ Gy. Ember, Az újkori magyar közigazgatás története Mohácstól a török kiüzéséig, Budapest 1946, pp. 484-485.

52 M. N y a k a s, Bocskai István, pp. 17-21., MNL OL MKA E 204. Missiles, Fasc. 6. István Bocskai to György Király (Gyalu, September 27, 1596); MNL OL MKA E 204. Missiles, Fasc. 6. István Bocskai to Márton Köveskúti (Gyalu, September 27, 1596); MNL OL MKA E 204. Missiles, Fasc. 6. István Bocskai to Márton Köveskúti (Gyulafehérvár, December 31, 1596); MNL OL MKA E 204. Missiles. Fasc. 6. István Bocskai to György Király (Kapjon, January 17, 1597); MNL OL MKA E 204. Missiles, Fasc. 6. István Bocskai to Márton Köveskúti (Gyulafehérvár, February 27, 1597).

53 L. Nagy, Iratok Bocskai István, pp. 70-71.

${ }_{54}$ MNL OL MKA E 204. Missiles, Fasc. 6. István Bocskai to Márton Köveskúti (Tarcsa, September 24, 1595).

55 MNL OL MKA E 204. Missiles, Fasc. 6. István Bocskai to Márton Köveskúti (Gyulafehérvár, February 1, 1596).

56 MNL OL MKA E 204. Missiles, Fasc. 6. István Bocskai to Márton Köveskúti (Gyulafehérvár, December 31, 1596).

${ }^{57}$ MNL OL MKA E 204. Missiles, Fasc. 6. István Bocskai to Márton Köveskúti (Gyulafehérvár, March 8, 1597).

58 MNL OL P 108. Rep. 46. Fasc. G. Nr. 235. Gergely Lippay to István Bocskai (Oláh-Kakucs, October 3, 1594).

59 MNL OL P 707. Missiles, XXXII. sor. Nr. 1631. István Bocskai to János Kereky (Várad, January 2, 1594).

60 MNL OL MKA Acta diversarum familiarum E 200. (in the following: E 200) 6. tétel/a. Missiles, fol. 4-5. István Bocskai to István Somlyai (Enyed, May 7, 1595). 
Bocskai participated as the Bailiff (supremus comes) of Bihar in the administration of the county, the Bihar county and its Vice-bailiff (György Ugray) forms a new cluster during this period. ${ }^{61}$ As a further and new cluster appears the correspondence with cities and their officials, where Beszterce of Transylvania and the chief justice of the city (Orbán Szabó) belonged. Beszterce was of high priority, because of border protection, by reason of its proximity to the Moldavian and Polish borders. The main subjects of this correspondence are the frontier protection issues. ${ }^{62}$

I registered István Szuhay, then the bishop of Vác, as the only person among the dignitaries of the ecclesiastical..$^{63}$ The number of unidentifiable alters, that can be categorized into other categories are three persons (János Horváth, ${ }^{64}$ Mihály Vér ${ }^{65}$ and Farkas Váncsa ${ }^{66}$ ).

Considering the territorial location, due to the growth of the social network, it became more diverse, the centre of correspondence remained in Transylvania, ${ }^{67}$ but it can be observed that several settlements of the Hungarian Kingdom (Eger; Kassa, present day Košice in Slovakia), the Kingdom of Czech (Poděbrady, Prague) have joined.

Comparing the previous and later lists of relationships, it can be demonstrated that only two persons - the Habsburg Emperor and Captain of Kálló - were permanently present among the 46 correspondents altogether. However, it is noticeable in both periods, that each group has fewer than ten members. In the course of collecting and analyzing Bocskai's correspondence, a total of twelve contacts can be detected in Bocskai's connection network during the examined time period, which could be identified just by testimonies. It is also clear, that the change in the social network of István Bocskai was mainly determined by relatives, the posts, positions held and the estates in the examined intervals.

${ }^{61}$ MNL OL MKA E 204. Missiles, Fasc. 6. István Bocskai to György Ugray (Gyulafehérvár, January 30, 1596); MNL OL MKA E 204. Missiles, Fasc. 6. István Bocskai to Márton Köveskúti (Gyulafehérvár, February 26, 1597).

${ }^{62}$ K. Benda (ed.), Bocskai István: Levelek, pp. 22-23; E. de Hurmuzaki, Documente privitóare, XII, p. 403.

63 ÖStA HHStA, Länderabteilungen, UA, AA, Kt. 131. Konv. B. fol. 132-133. István Bocskai to István Szuhay (Görgény, May 8, 1598).

${ }_{64}$ MNL OL MKA E 204. Missiles, Fasc. 6. István Bocskai to Márton Köveskúti (Gerend, April 17, 1596).

${ }_{65}$ MNL OL MKA E 204. Missiles, Fasc. 6. István Bocskai to Márton Köveskúti (Gyulafehérvár, December 31, 1596).

${ }_{66}$ MNL OL MKA E 204. Missiles, Fasc. 6. István Bocskai to Márton Köveskúti (Gyulafehérvár, February 26, 1597); MNL OL MKA E 204. Missiles, Fasc. 6. István Bocskai to Márton Köveskúti (Gyulafehérvár, February 27, 1597).

67 Enyed (present day Aiud in Romania), Feketehalom (present day Codlea in Romania), Görgény (present day Gurghiu in Romania), Gerend (present day Grind in Romania), Gyalu (present day Gilău in Romania), Gyulafehérvár (present day Alba Iulia in Romania), Kapjon (present day Coplean in Romania), Körösszeg (present day Cheresig in Romania), Oláh-Kakucs (present day Cacuciu Vechi in Romania), Sarkad, Szentjobb (present day Sâniob in Romania), Székelyhíd (present day Săcueni in Romania), Temesvár (present day Timișoara in Romania), Tarcsa (present day Tarcea in Romania), Újvár (present day Nové Zámky in Slovakia), Várad (present day Oradea in Romania). 
In my study I tried to show that on the basis of compiling and analysing an individual's correspondence, how the social network can be reconstructed, what focus points can be assigned to the analysis of a correspondence from the point of view of network, and what kind of results can be deduced as regards to composition, space and time dimensions.

\section{BIBLIOGRAPHY}

\section{Primary Sources}

HM HIM Hadtörténeti Levéltár VII/2. Törökkori gyüjtemény.

MNL OL Esterházy család hercegi ágának levéltára P 108. Repositorium 46, 98.

MNL OL Magyar Kamara Archívuma E 204. Missiles.

MNL OL Magyar Kamara Archívuma, Acta diversarum familiarum E 200. 6. tétel/a Missiles. MNL OL Zichy család zsélyi levéltára P 707 Missiles, XXXII. Sorozat.

ÖStA Haus-, Hof- und Staatsarchiv, Länderabteilungen, Ungarische Akten, Allgemeine Akten, Karton 127/128, 131.

Veress E. Zamoyski János kancellár levelezése magyarokkal (1576-1605), Magyar Tudományos Akadémia Könyvtár és Információs Központ Kézirattár, Veress Endre hagyaték, Ms. 433.

\section{Primary Sources Published}

Balázs M., "Ecsedi Báthory István levelei Bocskaihoz,” Irodalomtörténeti dolgozatok (Szeged) 1972, pp. 41-49.

Bayerle G., The Hungarian Letters of Ali Pasha of Buda 1604-1616, Budapest 1991.

Benda K. (ed.), Bocskai István: Levelek, n.p. 1992.

Fazekas I., "Négy levél Bocskai István bécsi és prágai tartózkodásához (1572, 1576)," Lymbus 2003, pp. 19-24.

Fraknói V. Dr., Károlyi Á. Dr., Magyar országgyülési emlékek. Monumenta Comitialia Regni Hungariae, X, Budapest 1890, pp. 606-612.

Hurmuzaki E. de, Documente privitóare la Istoria Românilor, III/1, Bucuresci 1880.

Hurmuzaki E. de, Documente privitóare la Istoria Românilor, IV/1, Bucuresci 1882.

Hurmuzaki E. de, Documente privitóare la Istoria Românilor, XII, Bucuresci 1903.

Hurmuzaki E. de, Documente privitóare la Istoria Românilor, XV/1, Bucureşti 1911.

Hurmuzaki E. de, Documente privitóare la Istoria Românilor, XV/2, Bucureşti 1913.

Jászay P., "A magyar nyelv történetének vázlata" [in:] A Magyar Tudós Társaság Évkönyvei. VI. 1840-1842, Buda 1845, pp. 261-297.

Juhász K., "List Štefana Bočkaja adresovaný mestu Banská Bystrica (Szerencs, 24. marca 1605.)," Acta Historica Neosoliensia 2016, no. 1, pp. 78-88.

Károlyi Á. Dr., Magyar országgyülési emlékek. Monumenta Comitialia Regni Hungariae, XI, Budapest 1899.

Károlyi Á. Dr., Magyar országgyülési emlékek. Monumenta Comitialia Regni Hungariae, XII, Budapest 1917. 
Kemény J., Nagy Ajtai Kovács I. (eds.), Erdélyország Történeti Tára egykorú s magyar nyelven készitett történetiratok-, levelek-, országgyülési végzések-és törvénycikkelyekböl, II, (1566-1613) Kolozsvár 1845.

Kemény L., "Bocskai István levelei Kassa városához,” Magyar Történelmi Tár 1904, pp. $458-473$.

Mikó I. (ed.), Erdélyi Történelmi Adatok I, Kolozsvár 1855.

Mikó I. (ed.), Erdélyi Történelmi Adatok III, Kolozsvár 1858.

Molnár A., Stefan Bocskay als Staatsmann und Persönlichkeit im Spiegel seiner Briefe, 1598-1606, 1983.

Nagy L., A Bocskai szabadságharc katonai története, Budapest 1961.

Nagy L., Iratok Bocskai István és kora történetéhez, Debrecen 2005.

Nagy L., "Okmányok a Bocskai szabadságharc idejéből," Hadtörténelmi Közlemények 1956, pp. 291-332.

Nagy I., Páur I., Ráth K., Véghely D. (eds.), Hazai okmánytár. Codex diplomaticus patrius $\mathrm{I}$, Györ 1865.

Nyakas M., A bihari kishajdú városok története, Debrecen 2005.

Nyakas M., Bocskai István váradi fökapitányt illetö levelek, Debrecen-Nagyvárad 2009.

Szabó K. (ed.), Erdélyi Történelmi Adatok IV, Kolozsvár 1862.

Szabó K., "Bocskai István politikai levelezése," Magyar Történelmi Tár 1882 (I, pp. 1-33; II, pp. 209-234).

Szalay Á., "Magyar régiségek," Tudományos Gyüjtemény 1831, no. 4, pp. 109-123.

Szalay Á., "Régiségek. Magyar levelek a XVIdik és XVIIdik századból," Tudományos Gyüjtemény 1830, no. 7, pp. 111-114.

Szilágyi S. (ed.), Erdélyi országgyülési emlékek. Monumenta Comitialia Regni Transylvaniae, IV, Budapest 1878.

Szilágyi S. (ed.), Erdélyi országgyülési emlékek. Monumenta Comitialia Regni Transylvaniae, V, Budapest 1879.

Szilágyi S., "Bocskai István és Illésházy István levelezése 1605-ben és 1606-ban,” Magyar Történelmi Tár 1878 (I, pp. 1-84; II, pp. 271-338; III, pp. 577-652).

Thaly K., "Bocskay István leveles könyve,” Magyar Történelmi Tár 1874, pp. 63-120.

Thaly K., "Levél Bocskaitól s Homonnai Bálinttól," Magyar Történelmi Tár 1881, pp. 583 585.

Vadász V., "Egy prédikátor levelei Bocskaihoz 1605 tavaszán,” Aetas 2005, no. 3, pp. 155161.

Veress A., Dr., Documente privitoare la istoria Ardealului, Moldovei şi Ţării-Românesti, IV, Bucureşti 1932.

Veress A., Dr., Documente privitoare la istoria Ardealului, Moldovei şi Ţării-Românesti, V, București 1932.

Veress A., Dr., Documente privitoare la istoria Ardealului, Moldovei şi Ţării-Românesti, VII Bucureşti 1934.

Veress E., Dr., Basta György hadvezér levelezése és iratai, I, Budapest 1909.

\section{LITERATURE}

Bagi Z.P., A császári-királyi mezei hadsereg a tizenöt éves háborúban. Hadszervezet, érdekérvényesités, reformkisérletek, Budapest 2011.

Bakács I., “A missilis,” Levéltári Közlemények 1966, no. 1, pp. 17-31. 
Balázs G., Kovács L., Szőke V. (eds.), Hálózatkutatás. Diszciplínák és metszéspontok, Budapest 2013.

Balázs G., Kovács L., Szőke V. (eds.), Hálózatkutatás. Interdiszciplináris megközelitések, Budapest 2012.

Balla P., "Báthori István király és Jan Zamoyski kancellár kapcsolata - egy sikeres együttmüködés története," Historia Nostra 2013, no. 1, 4-23.

Barabási A-L., A hálózatok tudománya, Budapest 2016.

Benda K., Bocskai István, Budapest 1993.

Ember Gy., Az újkori magyar közigazgatás története Mohácstól a török kiüzéséig, Budapest 1946.

Etényi N.G., Horn I., Szabó P., Koronás fejedelem. Bocskai István és kora, Budapest 2006.

Fazekas I., "Adalékok az ifjú Bocskai István bécsi udvarban eltöltött éveihez," Studia Caroliensia 2006, no. 1, pp. 73-85.

Feleky G.A., “Az egyén társadalmi beágyazottságának egoháló alapú vizsgálata,” Belvedere Meridionale 2012, no. 1, pp. 58-67.

Gyulai P., “Tanácsi tükör 1585” [in:] Janus Pannonius. Magyarországi humanisták, ed. T. K 1 a n i c z a y, Budapest 1982, pp. 1255-1266.

Hopp L., "A magyar levélmüfaj történetéből” [in:] Irodalom és felvilágosodás. Tanulmányok, eds. J. Szauder, A. Tarnai, Budapest 1974, pp. 501-566.

Horn I., A hatalom pillérei: A politikai elit az Erdélyi Fejedelemség megszilárdulásának korszakában (1556-1588), DSc doctoral thesis, 2012.

Horn I., “Az erdélyi hármastanács kormányzata (1583-1585)," Századok 2006, no. 4, pp. 883-925.

Horn I., "Bocskai István a Báthoryak udvarában," Publicationes Universitatis Miskolciensis. Sectio Philosophica 2018, no. 2, pp. 47-56.

Horváth Á.T., A Római Birodalom latin nyelvü levelezésének három évszázada, Szeged 2002.

Kovács D., "Az ecsedi udvar. Szervitori hivatás és kapcsolatrendszer Báthory István famíliájában," Századok 2016, no. 4, pp. 911-944.

Nagy L., A Bocskai szabadságharc katonai története, Budapest 1961.

Nagy L., Egy szablyás magyar úr Genfben (A sokarcú Bocskai István), Hajdúböszörmény 2002.

Papp S., "Egy Habsburg-követ, Simon Reniger oszmán kapcsolathálózata Konstantinápolyban. Vezírek, muftik, magyar renegátok," Aetas 2016, no. 3, pp. 40-53.

Papp S., Török szövetség - Habsburg kiegyezés. A Bocskai-felkelés történetéhez, Budapest 2014.

Sántha K., "Én-központú hálózatok kvalitatív elemzése," Neveléstudomány: Oktatás, kutatás, innováció (Budapest) 2016, pp. 54-66.

Szabó A., ,, Téged Isten dicsérünk”. Bocskai István, Erdély és Magyarország fejedelme, Budapest 2006.

Tóth S.L., A mezőkeresztesi csata és a tizenöt éves háború, Szeged 2000. 